\title{
Probabilistic Flood Defence Assessment Tools
}

\author{
Robert Slomp ${ }^{1}$, Han Knoeff ${ }^{2}$, Alessandra Bizzarri ${ }^{1}$, Marcel Bottema ${ }^{1}$ and Wout de Vries ${ }^{1}$, \\ ${ }^{1}$ Rijkswaterstaat, Ministry of Infrastructure and the Environment, PObox 22323500 GE Utrecht, the Netherlands \\ ${ }^{2}$ Deltares, PO Box 177, 2600 MH Delft, The Netherlands
}

\begin{abstract}
The WTI2017 project is responsible for the development of flood defence assessment tools for the $3600 \mathrm{~km}$ of Dutch primary flood defences, dikes/levees, dunes and hydraulic structures. These tools are necessary, as per January 1st 2017, the new flood risk management policy for the Netherlands will be implemented. Then, the seven decades old design practice (maximum water level methodology of 1958) and two decades old safety standards (and maximum hydraulic load methodology of 1996) will formally be replaced by a more risked based approach for the national policy in flood risk management. The formal flood defence assessment is an important part of this new policy, especially for flood defence managers, since national and regional funding for reinforcement is based on this assessment. This new flood defence policy is based on a maximum allowable probability of flooding. For this, a maximum acceptable individual risk was determined at 1/100 000 per year, this is the probability of life loss of for every protected area in the Netherlands. Safety standards of flood defences were then determined based on this acceptable individual risk. The results were adjusted based on information from cost -benefit analysis, societal risk and large scale societal disruption due to the failure of critical infrastructure e.g. power stations. The resulting riskbased flood defence safety standards range from a 300 to a 100000 year return period for failure. Two policy studies, WV21 (Safety from floods in the 21st century) and VNK-2 (the National Flood Risk in 2010) provided the essential information to determine the new risk based safety standards for flood defences. The WTI2017 project will provide the safety assessment tools based on these new standards and is thus an essential element for the implementation of this policy change. A major issue to be tackled was the development of user-friendly tools, as the new assessment is to be carried out by personnel of the institutions managing flood the defences, and not by just a small number of experts in probabilistic assessment. Therefore, data management and use of software are main issues that have been covered in courses and training in 2016 and 2017. All in all, this is the largest change in the assessment of Dutch flood defences since 1996. In 1996 probabilistic techniques were first introduced to determine hydraulic boundary conditions (water levels and waves (wave height, wave period and direction for different return periods). To simplify the process, the assessment continues to consist of a three-step approach, moving from simple decision rules, to the methods for semi-probabilistic assessment, and finally to a fully probabilistic analysis to compare the strength of flood defences with the hydraulic loads. The formal assessment results are thus mainly based on the fully probabilistic analysis and the ultimate limit state of the strength of a flood defence. For complex flood defences, additional models and software were developed. The current Hydra software suite (for policy analysis, formal flood defence assessment and design) will be replaced by the model Ringtoets. New stand-alone software has been developed for revetments, geotechnical analysis and slope stability of the foreshore. Design software and policy analysis software, including the Delta model, will be updated in 2018. A fully probabilistic method results in more precise assessments and more transparency in the process of assessment and reconstruction of flood defences. This is of increasing importance, as large-scale infrastructural projects in a highly urbanized environment are increasingly subject to political and societal pressure to add additional features. For this reason, it is of increasing importance to be able to determine which new feature really adds to flood protection, to quantify how much its adds to the level of flood protection and to evaluate if it is really worthwhile. Please note: The Netherlands government policy is to develop open source models.
\end{abstract}

\section{Dutch flood Risk Management Policy}

In 1958, the flood risk standards for coastal areas were formally laid down in national law [Deltawet,1958]. These standards were based on a cost benefit analysis [van Dantzig, 1956] made for the most densely populated area of the Netherlands. An area that is protected by a single continuous line of flood defences. Today, this area comprises the largest part of the urban agglomeration (in the form of a circle) called the Randstad. It includes the cities of Amsterdam, Leiden, Delft, The Hague, Rotterdam and the new developed western part of the city of Utrecht (Leidsche Rijn). This flood prone area corresponds with dike ring 14 (see figure 1). A dike ring is comprised of a continuous line of flood defences, consisting of dunes, structures and/or dikes (see figure 2).

\footnotetext{
${ }^{\text {a }}$ Corresponding author: Robert.slomp@rws.nl
} 
This flood defence system currently protects approx. 3,6 million people.

In 1956, the exceedance of design water levels was used as a proxy for the probability of flooding. In 1956 models to evaluate more failure modes in a risk analysis were not available. The first operational models were developed between 1980 [Bakker and Vrijling 1980], [Graaff van de, 1986] and 1990 [CUR, 1990].

In 1996, formal flood risk standards for all $3600 \mathrm{~km}$ of primary Dutch Flood defences (figure 1) were laid down in the Flood defences act [Wet op de waterkering, 1996]. These standards were based on a mixture of policy decisions and regional cost benefit analysis [MNP, 2004].

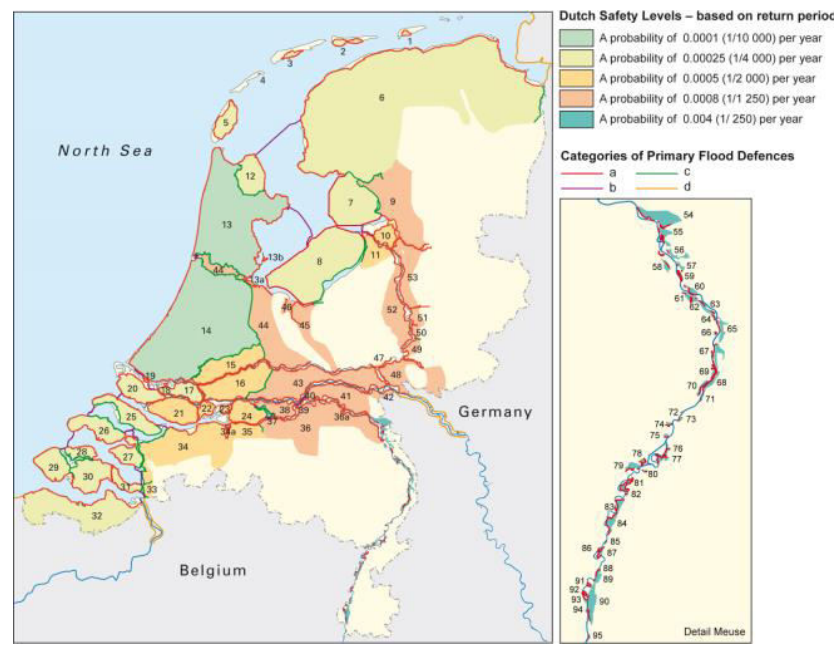

Figure 1. Current flood risk standards for flood defences in the Netherlands.

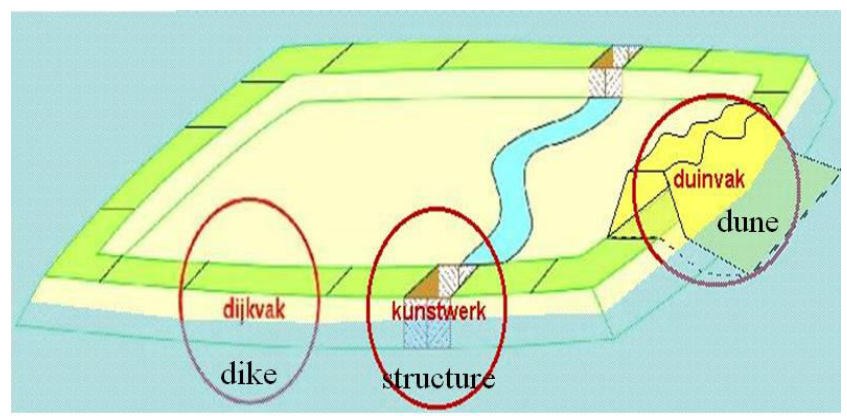

Figure 2. The concept of a dike ring, a continuous line of flood defences (dunes, dikes, hydraulic structures)

The dike ring approach was chosen, given the principle that a chain is as strong as its weakest link. Based on this approach ${ }^{\mathrm{a}}$, during the last seven decades the 2500 water boards merged into 23 regional water authorities. At present, each dike ring (except for two dike rings) is managed by a single water authority. According to the Flood defence law, all primary flood defences had to be assessed every 5 years. For this assessment, the national government developed guidelines, including the assessment method and tools to determine the hydraulic loads.

\footnotetext{
a This concept was probably developed in 1939 by the "Stormvloed Commissie", committee on storm surges, see the biography of Johan van Veen. "https://nl.wikipedia.org/wiki/Johan_van_Veen
}

In the period $2009-2012$, formal flood risk-based standards for the $15000 \mathrm{~km}$ of secondary or regional flood defences were given by the respective provincial governments An example of this are the standards set by the province of South-Holland [VenW, 2009]. Flood Defence assessment tools for regional Flood Defences, have been developed through funding by STOWA $^{\mathrm{b}}$. DAM, the "Dike Assessment module" was developed for geotechnical assessments [van Zwan, Vastenburg, 2013], [Peters, and van den Berg,, 2016] and Promotor was developed to determine Hydraulic Loads [Bakker et al, 2010].

The major differences between assessment tools for primary and regional flood defences are the funding structure and the required level of the assessment ${ }^{c}$. On technical level, there are few differences. The basic difference is that no casualties are expected in the case regional flood defences fail, therefore the standards are less stringent. This paper only covers assessment tools for the primary flood defences.

All laws and changes to laws are available on the internet; the references in this article to current, past and future legislation are internet links.

\subsection{Underlying studies of the new safety approach}

The WV21 "Water Veiligheid 21e eeuw", a policy study (flood risk safety analysis for the 21st century) using the probabilistic Hydra-models of the WTI2011 (formal assessment tools of 2011) carried out a national flood risk assessment for the Netherlands [Kind, 2010]. [Kind, 2010] used the Optimalisering model [Brekelmans et al, 2014] for the Cost Benefit Analysis. Climate change and economic growth were important variables in this study. The probability of flooding was determined using the failure modes overflow and overtopping.

Simultaneously, the VNK2 "Veiligheid Nederland in Kaart" was carried out, a national safety analysis [Jongejan et al, 2011]. The VNK2 study determined the actual flood risk for the situation in the year 2010. The probability of flooding was determined by using a fully probabilistic model PC-ring [Vrouwenvelder, 2001]. The main failure modes for flood defences that were covered in the model for dikes were geotechnical failure (piping and inner slope failure), outer revetment failure (grass, asphalt and stone) and subsequent failure of the underlying layers, overtopping and overflow and subsequent erosion of the inner slope. The considered failure mode for dunes was erosion due to wave action. The considered failure modes for hydraulic structures were overtopping, structural failure, non-closure, stability of the structure and piping. Implementing knowledge uncertainties in determining the probability of flooding for flood defences along rivers was experimented on in a

\footnotetext{
${ }^{\mathrm{b}}$ The research institute for regional water authorities.

${ }^{\mathrm{c}}$ In the Netherlands, research and development of software flood assessment tools are carried out jointly by experts from the same teams.
} 
study on the usefulness of emergency storage areas [Stijnen et al, 2008].

Flood damages in the WV21 and VNK-2 studies were determined by using overland flow models as FLS [Duinmeijer, 2002] and flood damage curves [Kok et al, 2004]. For the WV21 study, the cost of reinforcements or new flood defences were determined in the mode KOSWAT [Grave P., 2014] by using information of reconstruction and reinforcement of flood defences of the past 20 years.

\subsection{New flood defence policy}

The WV21 and the VNK2 studies, provided the required technical information for the new risk based standards for flood defences. The VNK2 project proved that the probability of flooding based on the failure modes can be described. Hence, the new policy will be based on maximum allowable probability of flooding. It is expected that these new standards will become formal on January 1st 2017 through an update of the "Water Act" [IenM, 2016].

Since January 2014, the WTI2017 method has been introduced in all new flood defence (re)construction projects. This approach was adopted in anticipation of the coming formal change of flood defence policy.

The WV21 study showed it was possible to abandon differences in expected design water levels proxy for flood risk assessment used by [van Dantzig, 1956]. The WV21 study used the differences in desired crest level as proxy for flood risk. Geotechnical issues were addressed in the cost of reinforcements. VNK-2 data was used to correct the probability of flooding.

The new risk-based standards for flood defences vary greatly. The maximum probability of failure varies from $1 / 300$ per year to $1 / 100000$ per year (figure 3 ). The main reason for this great variety is the difference in risk for each area.

\subsection{The flood defence assessment}

A major issue, which had to be tackled in the WTI2017 project, was that the tools were to be used by technical staff of flood defence managers, not by experts in flood defence probability. This is a major change in the assessment of flood defences since 1996, when probabilistic techniques were first introduced for determining hydraulic boundary conditions for assessment and design water levels and waves (wave height, wave period and direction for different return periods).

Within the current flood defence approach, every dike ring has a uniform safety level, expressed in the probability of exceedance. Consequently, for every cross section hydraulic loads were determined (waves, water levels) that corresponded with this standard. So, there is a uniform safety norm along the entire dike ring.

As the new approach is based on the flood risk, the character of the safety norm changes drastically. As now the effects of a flood inside a dike ring are considered uniform (based mainly on individual risk), the safety standards along the dike ring vary. For different water systems the extent of flooding and speed of flooding is different. That is why new safety standards consider dike sections instead of dike rings [van der Most et al, 2014].

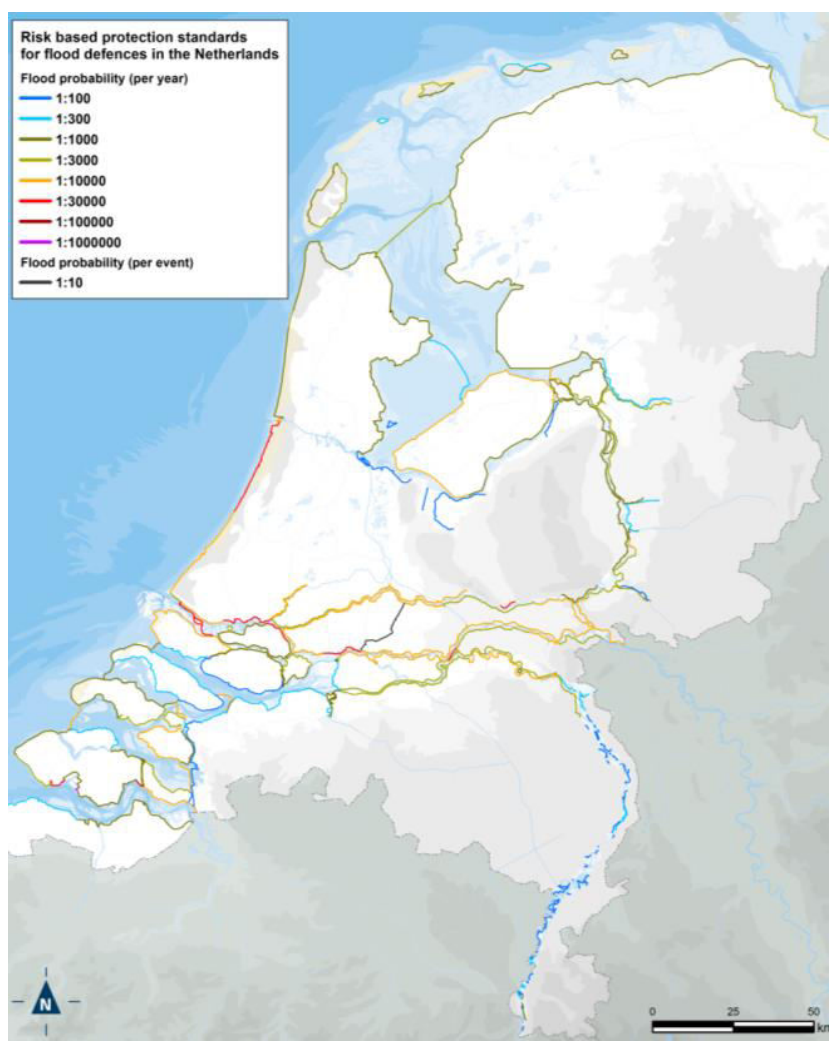

Figure 3: Risk-based safety standards for flood defences valid from $1 / 1 / 2017$.

The new safety standards have been based on individual risk, societal risk, and cost benefit analysis [Slomp, 2012] and [Most et al, 2014]. The background of breaking up dike rings into sections is illustrated by [Nillesen and Kok, 2015] for a dike ring along two Rhine river branches and the tidal area of the Rhine river.

From January 1st 2017 these flood risk based standards will vary from probability of 0,0033 to 0.00001 per year (figure 3). These new risk-based safety standards for flood defences differ greatly in form and use from the current standards. One can also note that safety standards along the Rhine branches and some deep polders have become rather stringent, mainly due to the large consequences of flooding in these areas.

In general, it is not cost-effective to build extra dikes to partition large dike rings into smaller dike rings [Moll and Meulepas, 2008]. Such compartmentation dikes have proven to increase resilience when primary flood defences do not meet the standards or when primary flood defences are badly maintained. However, these dikes can increase casualties when the flood prone areas are relatively small (due to high rising rates of the water e.g. meters within an hour). This was for instance the case in the 1953 storm surge disaster in Zeeland. The only compartmentation dike which retained its formal status is indicated in black in figure 3 . Since 1277 , due to military and economic reasons, a secondary flood defence 
line was built and maintained, the "Diefdijk", Floods from upper river areas could be contained in a designated flood retention area and diverted back to the river after the passage of a flood wave on the main river. The background is that flood flows through a polder take more travel time than through the main river; the time lag can be in the order of a week [Ham van der, 2004]. The same area designated to contain a flood could also be artificially flooded through gates in case of a military threat. Long term spatial planning was provided by the military since the $18^{\mathrm{h}}$ century and after the forts lost their purpose in 1950, by national and provincial governments. The latter maintained the flood storage area by allowing only sparse urban development.

\section{Flood Defence Assessment, Dutch experiences}

\subsection{Recent experiences}

Formal flood risk assessment started in 1996. A first assessment report to parliament was submitted in 2001. Based on the outcomes, national budget to improve water defences up to the required standard was allocated. The assessment results were binary: a flood defence either complies to or fails the legal standards. In case of noncompliance, the assessment results could not give an indication of how far the demands were not met. So, these results could not be used for priority setting of flood defence improvement works. In addition, 'no formal result' could be given for about $38 \%$ of the flood defences, [VenW, 2001]. This, because the assessment tools had some shortcomings.

Since 1996, three formal assessments were carried out 1996-2001, 2001-2006 and 2006-2011. In the course of these assessments, the percentage of no formal result remained high. This is one of the reasons that the fourth assessment (2011-2017) was suspended. The second reason is that the number of dike improvement works, resulting from the third assessment, was too high to be realized within the next 6 years.

In the period 2011 - 2014, efforts were at reducing the number of dike stretches with no formal assessment result. There are two main reasons why the percentage 'no formal result' remained high.

- Not all formal rules and software were available at the start of each assessment period. This also meant that training material was not available on time.

- Difficulties in getting the required data (especially getting data on the subsoil, the exact materials contained in the dike and the properties and strength of historical sluices).

In the National Water Plan of 2009 [VenW, 2009], a new policy measure was announced. A binary approach was not considered to be efficient, as the number of dikes to be reinforced became higher than the available budget for the allocated time to carry out the required reinforcements as to be able to comply with the legal standards. Therefore, the assessment of 2017 - 2023

\footnotetext{
${ }^{\mathrm{d}}$ https://nl.wikipedia.org/wiki/Diefdijk_\%28dijk\%29
}

should provide for additional information to make prioritization of funds for reinforcement possible. To deliver this information, the tools to carry out the assessment should be more accurate. Probabilistic tools provide this information. The former semi-probabilistic tools based on safety factors also provide information to what extent on how much a flood defence does not meet (i.e. exceeds) the safety standards, however the information was not used. A binary approach simplifies the process during the assessment and the funding. With just semi-probabilistic tools, it was difficult to combine information from different failure modes, and to come to an indication of how much a flood defence did not meet the legal standards. A full probabilistic approach makes this feasible.

\subsection{The assessment of flood defences}

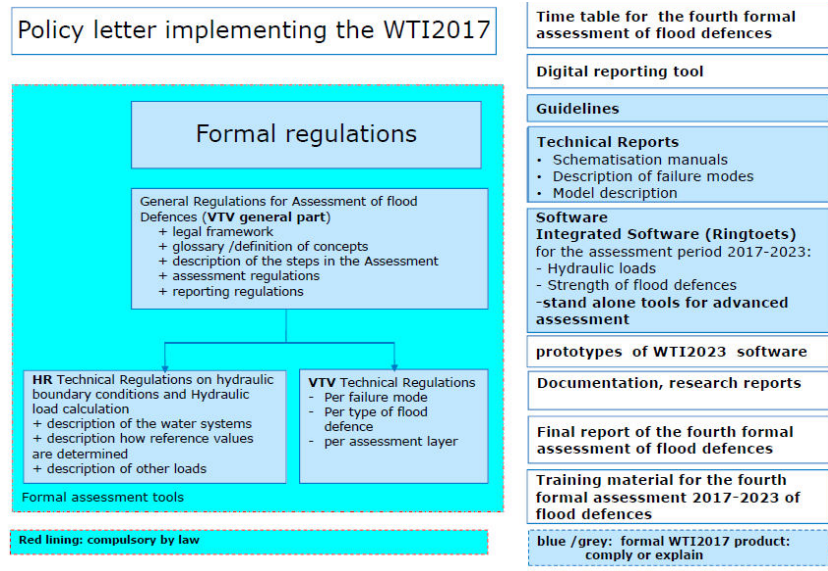

Figure 4: Formal and informal flood defences assessment tools

The flood defence assessment tools are a combination of formal and informal instruments (figure 4). Some rules and regulations are set by law (left side of figure 4), other formal rules (in blue/ grey) and instruments have to be used except if they are not applicable. The principle of comply or explain has to be applied for these rules and software.

Assessment of flood defences essentially means comparing the strength of a flood defence structure with the expected Hydraulic loads. The ultimate limit state of the strength of a flood defence is determined for certain assessment/design loads. In the past, essentially a serviceability state was used for assessments, as managers wanted flood defences to be accessible for emergency measures during a storm. The serviceability state is a more conservative approach. Other conservative approaches have also been implicit in the current assessment rules (see the next section on semiprobabilistic versus probabilistic approach).

Determining the ultimate limit state means describing the uncertainties for both the hydraulic loads and strengths of flood defences in a consistent way. For the WTI2017 project, this is described by [Diermanse, 2016]. In the past, model uncertainties and statistical uncertainties were not considered for hydraulic loads. This was a national policy choice. Statistical variability of hydraulic loads was considered through the "Hydramodels" (see chapter 3). In general, adding statistical 
uncertainties in a wind driven system like Lake Ijssel adds $1 \mathrm{~m}$ to the required dike height [Meermans, 1999].

The Hydraulic loads required for the assessment depend on the formal risk-based standards for flood defences (figure 1). The Hydraulic loads are often expressed in design or assessment water levels or in the combined hydraulic load of water levels and wave action for a given return period or probability, often expressed as a required dike height (for a given critical overtopping limit e.g. 1 of $0.1 \mathrm{l} / \mathrm{s} / \mathrm{m}$.)

A mathematical description of the full failure process often does not exist. To determine the ultimate limit state of flood defences, one would like to determine the exact moment of failure. This is often not possible. Sometimes only empirical models like the wave run-up model [van der Meer, 2002] are available. Process based models are preferred, because uncertainties can be modelled accordingly. However process based models often only describe part of the failure process. The Sellmeijer model [Sellmeijer, 1988] with piping serves as an example. It describes the transport capacity of an erosion pipe beneath a flood defence. However, it does not describe how many sand particles get detached to be transported [van Beek, 2015]. The transport capacity is larger than the number of particles which will detach themselves. Information from [van Beek, 2015] is therefore needed to determine a more precise definition of failure for piping. It will take a number of years to develop a working model for this. In other words, using the Sellmeijer formula implies a rather conservative approach of the failure mechanism piping.

Given the difficulties mentioned above, a mix of empirical and processed based models has been used pragmatically in the project. In every assessment period, models are improved so that modelling the exact moment of failure of flood defences gets closer. However, it will be impossible to determine the exact moment of failure, due to model constraints (in time and scale) and uncertainties in both hydraulic loads and properties of the flood defences and subsoil.

\subsection{Semi-probabilistic versus probabilistic approach}

In a semi-probabilistic or deterministic approach, an expected design maximum load ( $\mathrm{S}$ ) for a design period is compared with the expected design strength of a structure (R) (see figure 5) [Vrouwenvelder, 2008]. To pass the safety assessment, the strength of a structure has to be higher than the expected load $(\mathrm{R}>\mathrm{S})$.

A safety factor is often added to the expected strength, as to be certain that the outcome is sufficiently safe. This safety factor can be relatively large, due to formal rules or due to policy choices for building codes or design codes. Using large safety factors, however, is not very cost-efficient.

A full probabilistic approach is more cost-efficient in both design and assessment. The first application of probabilistic methods for Dutch flood defences was in the design of the Delta Works. The design team realised that superposition of worst-case assumptions of different hydraulic load components lead to clearly conservative results [Vrijling and Bruinsma, 1980].
Vrouwenvelder developed the probabilistic PC ring model for flood defences [Vrouwenvelder, 1999, 2001], which was used in the VNK-2 project. This PC ring model was also used at the start of the WTI2017 project to determine the first safety factors for flood defences in 2010 using the national data sets for flood defences of the VNK-2 project.

In 2017 , all safety factors will be determined by using the new software. This consistency between probabilistic tools and semi-probabilistic tools is essential in the WTI2017 approach.

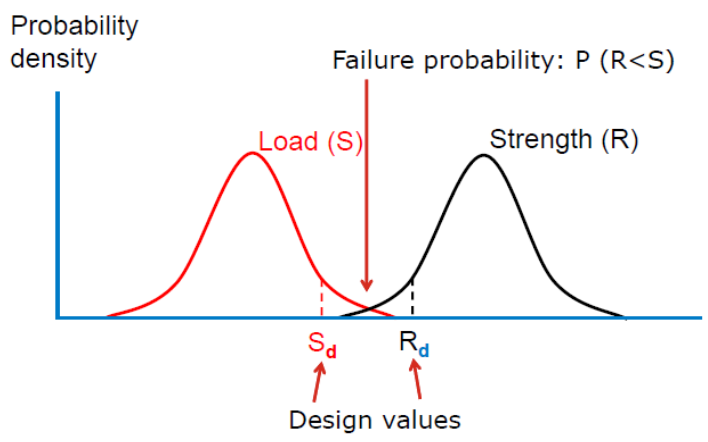

Probabilistic assessment: evaluate whether $\mathrm{P}(\mathrm{S}>\mathrm{R})<\mathrm{P}_{\text {required }}$ ? Semi-probabilistic assessment: evaluate whether $S_{d}<R_{d}$ ?

Figure 5. How a structure is assessed both using probabilistic and semi-probabilistic assessment, the figure also shows the relationship between both techniques.

The main issue in both semi-probabilistic and probabilistic modelling is the determination of which factors to be included in a full probabilistic how to provide all the data to run such a model properly. In a semi-probabilistic approach, one often adds safety factors in case a variable cannot be modelled correctly. In a probabilistic model, adding all theoretical stochastic variables results in a scientifically correct model, which however will never be able to run.

Both dilemmas have to be addressed pragmatically. Replacing stochastic variables with good mean values can significantly reduce the number of variables in probabilistic models, whereas this will not lead to a poorer result. This process takes time, as it is based on past experience, trial and error. In this way, such a model improves step by step over time.

Other models are often needed for calibration purposes. One of the main issues for system reliability is modelling the spatial correlation of interdependent variables. This is an issue for both hydraulic load modelling and strength modelling. The latter was also covered by [Vanmarke, 2011]. For Hydraulic load modelling, this was successfully achieved in an theoretically sound way [Geerse, 2011]. This was possible by using Hydrodynamic models as WAQUA [Rijkswaterstaat, 2012], SWAN [Zijlema, 2007] and SOBEK [Deltares, 2016], by interpolating between the sites with sufficiently long time series where water levels and waves are measured and combining the information in the Hydra-Model [Geerse, 2011]. For the strength models piping and slope stability, a number of assumptions were made based on information on 
geological deposits under flood defences and how the failure modes are modelled [Vrouwenvelder, 2006] and [Roescoe et al, 2016]. These assumptions have made it possible to build the model however they are not ideal; the choices remain black boxes for many involved in flood defence assessment.

In the case of flood defences (dikes, dunes and Hydraulic structures), hydraulic loads are the determining loads for design or assessment purposes. The expected mean maximum load is considered for different return periods, expressed in the probability per year. In the Netherlands these values currently vary from a probability of 0.004 per year (river dikes along the Meuse to 0.0001 per year for coastal flooding, see figure 1 ).

\subsection{Failure modes}

In the 2006-2011 assessment, approximately 40 failure modes were considered. Figure 6 represents a simplified fault tree for flood defences. In WTI2017, however, rules will focus on the most relevant failure modes (about 20, see Figure 6).

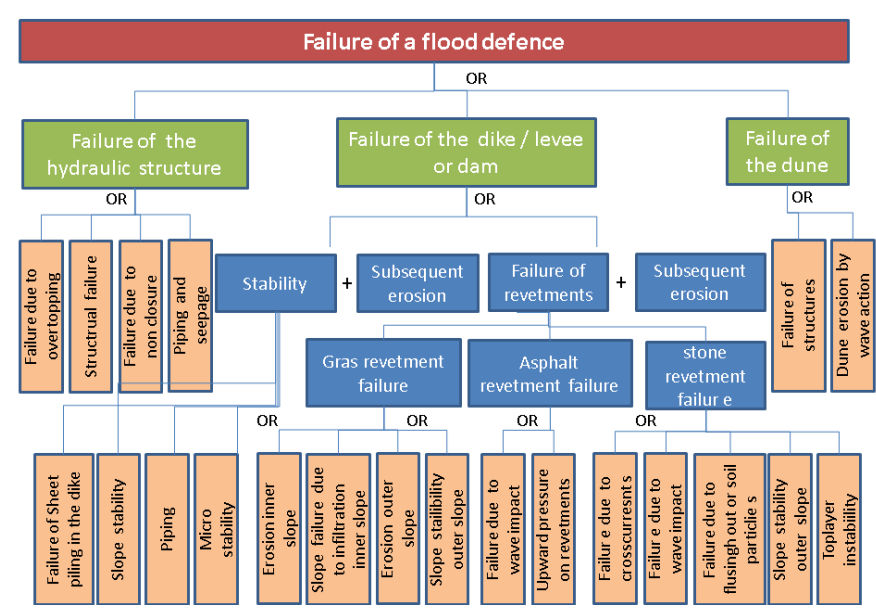

Figure 6. Fault tree for flood defences

In the 2017-2023 assessment, all inspection techniques which relate to maintenance are no longer part from the formal assessment. These are now separately monitored by flood defence managers ${ }^{\mathrm{e}}$. These inspections are to be carried out regularly ( $2-3$ times per annum), to allow for a timely repair as to maintain the condition of the flood defences. In addition, inspections are to be carried out directly after storms and high river discharges. The inspection results and related repair works are to be achieved in a transparent way. Note that some damages, like foreshore failure, slope-instability or severe revetment damage, cannot be repaired in a short period.

Other examples of assessments which have changed, concern, the risk of failure due to the occurrence of pipes, cables and other types of structures (e.g. trees, utilities and houses) in and on flood defences. These failure modes can be considered as scenarios in the formal assessment. Each scenario is given a certain probability.

\footnotetext{
${ }^{\mathrm{e}}$ The Inspection of the Ministry of Infrastructure and Environment is responsible to verify this process.
}

Three main types of flood defences are considered: hydraulic structures, dikes and dunes. In addition, transitions between these structures and hybrid structures also have to be assessed. The latter two are covered in paragraph 2.7. In figure 6 a simplified fault tree has been shown. Figure 7 shows each failure mode schematically.
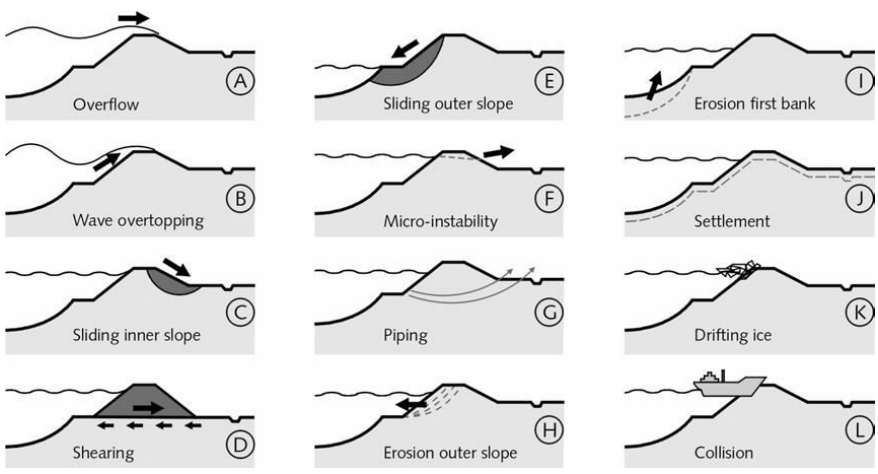

Figure 7a. A summary failure modes [TAW, 1998]

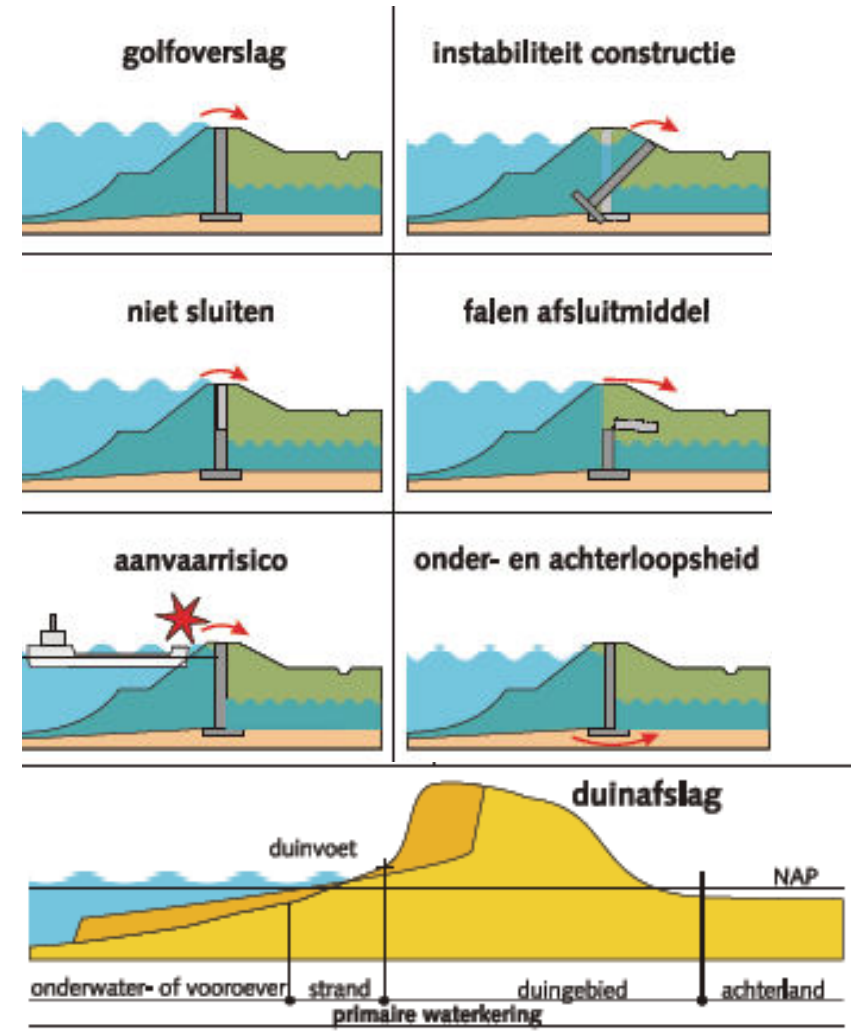

Figure 7b. A summary of the flood defences

Assessment rules for hydraulic structures and dunes, [TAW, 1998]

\subsection{Hydraulic loads -using more and more climate data}

According to the Water Act, every 6 years the underlying data of Hydraulic loads has to be updated and the hydraulic loads have be recalculated. From 2023 onwards, the frequency will change to once every 12 years. Observed climate change and measures which influence hydraulic boundary conditions, like the Room for the River project [Slomp, 2012] have to be accounted for in each update. 
Statistical data from a large number of sites which measure wind speed, discharges and water levels have been used to determine extreme conditions. Time series for water level and discharge measurements vary from 100 to 200 years [Chbab et al, 2002] and [Chbab, 2016]. In most cases, data over the last century are sufficiently reliable (with one or more than one measurement per hour). For determining extreme river discharges, climate models are used to produce additional statistical data based on 50000 years of generated discharges of the Rhine and Meuse rivers. For this, the generated rainfall and discharge extremes are determined by the GRADE model; a model that took 20 years to be developed. In essence a time series of 50000 years of discharges is generated by using about 30 years of climate data [Hegnauer et al, 2016].

For determining extreme storm surges at the North Sea, a similar method is used with a generated time series of 3500 years. This data was used to verify the statistical extrapolation and to determine the statistical uncertainties [van den Brink, 2015].

\subsection{A layered assessment}

The assessment will follow a three step approach (see figure 8), simple assessment, detailed assessment and advanced assessment. A second detailed assessment layer is added: the full probabilistic assessment. For the Dutch community of engineers involved in assessment, design and maintenance, it will take time to understand the step towards a full probabilistic approach. This three step approach is therefore important for educational purposes and consists of:

-A simple assessment, to determine if the flood defence has to be assessed for a certain failure mode: Does the failure mode to be considered has a negligible contribution to the probability of failure? This is based on the relevance of the failure mode, on whether a hazard for the flood defence exists independent of the hydraulic load or whether the Hydraulics loads will never endanger the flood defence. The purpose of this assessment is to reduce the amount of data one has to collect. It is expected that in the coming years, the cost of data collection and analysis can be reduced by using more and GIS based tools. By then, this first step will become less relevant. $^{\mathrm{f}}$

-The second step, a detailed assessment, consists of two sub-steps:

- The first sub-step 2a comprises:

- for dikes a semi-probabilistic analysis of geotechnical issues and outer revetments for narrow homogeneous sub-sections (50 to $100 \mathrm{~m}$ wide).

\footnotetext{
${ }^{\mathrm{f}}$ For Dunes erosion, failure of the stone revetments on the outer slope and height of flood defences/inner grass slope failure due to erosion the simple assessment is no longer required. All data is readily available for a detailed assessment in regularly updated digital terrain maps (e.g. AHN2 http://www.ahn.nl/pagina/viewer.html) and in the ledgers of the flood defences.
}

- For hydraulic structures a probabilistic approach for overtopping and inner slope erosion, for narrow homogeneous sections sub-sections (50 to 100 meters wide) or overtopping.

- The second sub-step (2b) comprises a full probabilistic analysis for all failure modes ${ }^{\mathrm{g}}$ per full 5-20 km section of a dike ring (see figure 3). For each failure mechanism, these full sections may be composed of several independent sub-sections.

- The third step comprises an advanced assessment. New research can be used here. The WTI2017 project gives advice on what is available on the National website http://www.helpdeskwater.nl/.

One can use the new research, after one has shown that this research is relevant for the purpose of the assessment of flood defences. Transitional structures and hybrid structures (e.g. dike in a dune) can be assessed this way. A dike in a dune can also be assessed using formal tools (thus in step 2), but it can then only be assessed as a dike. The residual strength provided by the dune can be assessed separately. The experimental model Xbeach can be used [Roelvink et al, 2009] in Morphan [Lodder en Geer, 2012] to evaluate hybrid structures like dikes in dunes and the influence of structures on dune erosion (e.g. bunkers from the Atlantic Wall).

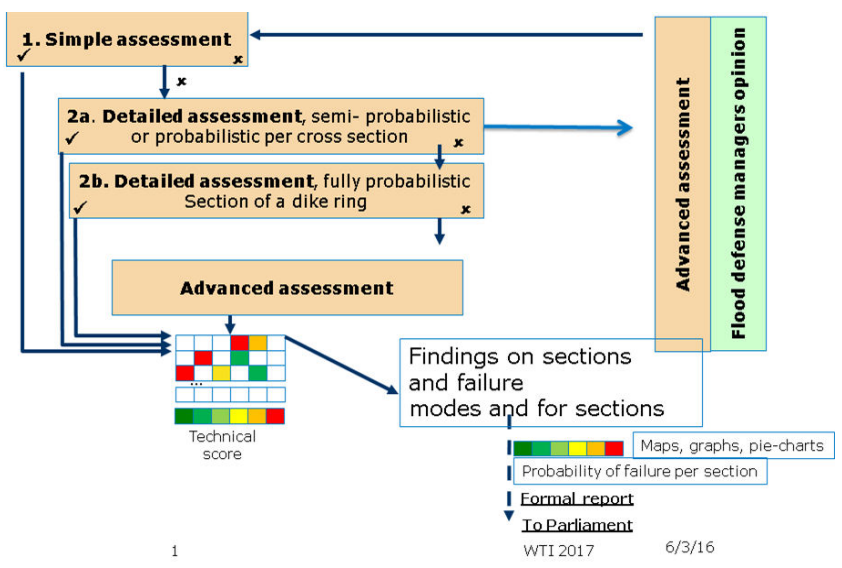

Figure 8. A layered approach for flood defence assessment

\subsection{Calibration process, determining safety factors for semi-probabilistic assessment}

For the detailed semi-probabilistic assessment, new semi-probabilistic assessment rules were determined by using full probabilistic models. This process is called the calibration procedure and is covered in [Jongejan and Calle, 2013]. This calibration procedure consists of the following steps (see also Figure 9)

(1) The first step is to establish a reliability requirement. This is carried out for all failure

\footnotetext{
${ }^{g}$ Note: Assessment of revetments on the outer slope is possible in a full probabilistic model (PC-ring). It uses approximate descriptions for the failure modes. It is available for advanced assessment.
} 
mechanisms separately. Each mechanism has a maximum allowable contribution to the probability of flooding (table 1). This is a choice based on experience with design practices and the performance of existing dikes and dunes. This requirement is defined as a maximum allowable probability of failure for the failure mechanism under consideration. In practice, length effects are also accounted for, as the semi-probabilistic assessment takes place on relatively narrow sub-sections of a dike.

(2) The second step is to carry out probabilistic and semi-probabilistic analyses for a set of cases for a selection of flood defences. This step comprised of the following, closely related activities:

. Decide which stochastic variables and safety factors are to be included in the semi-probabilistic assessment rule.

. Select a characteristic set of cases (test set). These may concern existing or generalized, so fictitious, crosssections of levees, dunes or hydraulic structures, depending on the type of failure mechanism considered. In the WTI2017 project, the VNK-2 national data sets were selected for this purpose.

. Modify the members of the test set, so that they comply with the semi-probabilistic assessment rule, that is, by changing the height or width of the cross-sections for different values of the safety factors.

Calculate failure probabilities for each case, that is, for every modified member of the test set.

(3) The third step is to apply a calibration criterion to select the safety factor(s). This is based on the outcomes of the probabilistic analyses. The values of the safety factor(s) are chosen such that a predefined calibration criterion is met. The calibration criterion provides a reference for deciding which values of the safety factors are sufficiently safe.

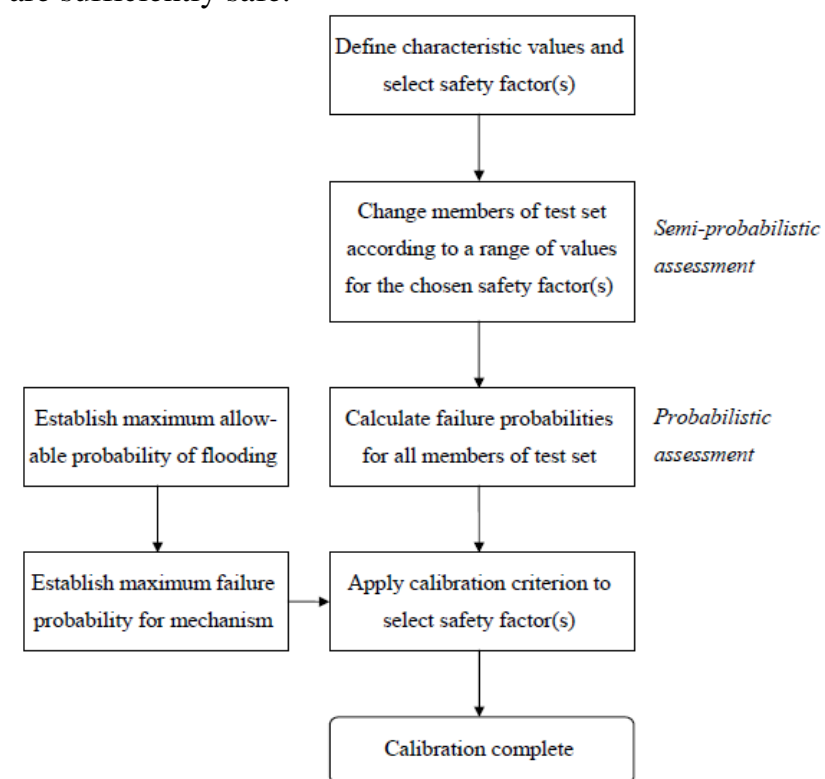

Figure 9. Schematic overview of the calibration procedure [Jongejan and Calle, 2013]

The use of these safety factors in the semiprobabilistic assessment is a more conservative approach than that of a full probabilistic analysis. The advantage of the semi-probabilistic assessment (layer $2 \mathrm{a}$ in figure 8 ) is to quickly determine if a flood defence fulfils the standards for flood defences. If it fails the assessment, one has to continue with the full probabilistic analysis in layer $2 \mathrm{~b}$. The maximum allowable contribution to the probability of flooding per failure mode is a project choice and has been documented in [De Waal, 2014 and 2016].

\begin{tabular}{|c|c|c|}
\hline & \multicolumn{2}{|c|}{ Type of flood defence } \\
\hline & Dunes & Dike/levee \\
\hline Overflow and wave Overtopping & 0,0 & 0,24 \\
\hline piping, heave and .. & 0,0 & 0,24 \\
\hline Slope stability & 0,0 & 0,04 \\
\hline outer revetment failure & 0,0 & 0,10 \\
\hline $\begin{array}{l}\text { failure due to non- closure of } \\
\text { hydraulic structure }\end{array}$ & 0,0 & 0,04 \\
\hline piping at a hydraulic structure & 0,0 & 0,02 \\
\hline $\begin{array}{l}\text { structural failure of a hydraulic } \\
\text { structure }\end{array}$ & 0,0 & 0,02 \\
\hline Dune erosion due to wave action & 0,70 & $0 / 0,10$ \\
\hline $\begin{array}{l}\text { other failure modes } \\
\text { (no probabilistic model available) }\end{array}$ & 0,30 & $0,30 / 0,20$ \\
\hline Total & 1 & $\mathbf{1}$ \\
\hline
\end{tabular}
probability of flooding

\section{Software}

Software only works if the necessary models and data are made available. Figures 10, 12, 13 and 14 give examples of the workflow and the software tools . Data management issues themselves are covered in chapter 3.

The current formal software for both the assessment and for design, are the Hydra-Zoet [Geerse, 2011] and Hydra-K [den Heijer et al, 2008]. These focus on dike overflow and overtopping. These models will be replaced by the model Ringtoets, which has a full probabilistic kernel "Hydra-Ring" [Roscoe et al, 2012].

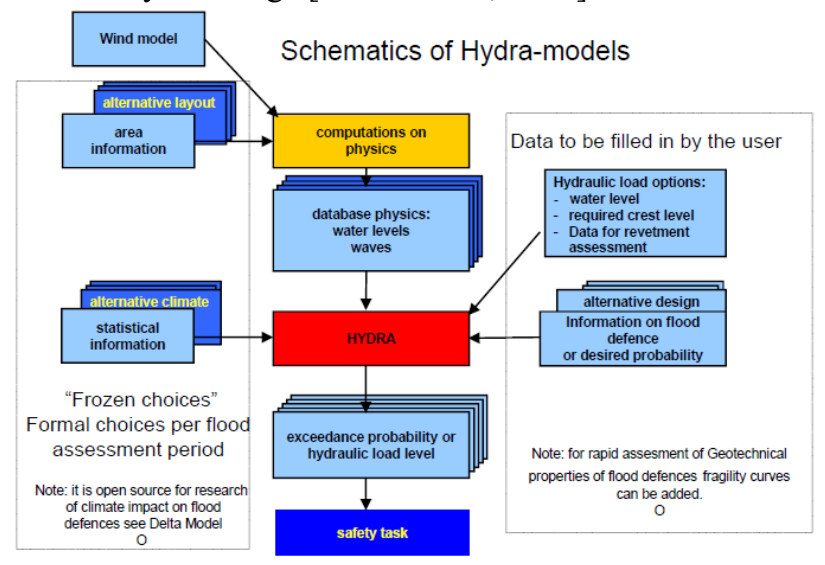

Figure 10. Hydra-Schematics for determining Hydraulic loads

The main concept of Hydraulic load models, the Hydra-models [Geerse, 2011], is that a large database is prepared with all states of the water system for situations varying from a 1 in 10 year event to a 1 in 100000 year event (figure 10). Water level statistics for coastal stations, discharge statistics and wind statistics are determined for each stochastic variable for the entire frequency range mentioned above. The models can be used for assessment, design and policy studies [Slomp, et al, 2014]. 
The Hydra-models primarily use the overflow/ overtopping failure mode description. With these models, all possible wave run up or overtopping situations can be determined. Further, each situation can be weighed, to determine the probability of failure or the desired assessment height (depending on the input). If the probability of failure is desired the flood defence including its height is entered in the model. In case the desired dike height is desired, only the flood defence orientation, slope and roughness properties need to be schematised.

The different states of the water system are calculated by using hydrodynamic models such as WAQUA (water levels, currents) and SWAN [Zijlema, 2007] (waves). For each state, the maximum combinations of water levels and waves are filtered out [Santbergen, 2005] for deep water locations (coast), locations on the river axis ("thalweg"), just in front of the foreshore and near the flood defence (figure 11).

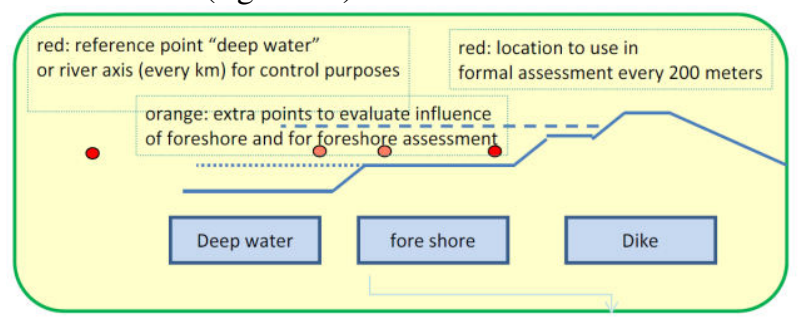

Figure 11a. Location for hydraulic load data for dikes (cross section)

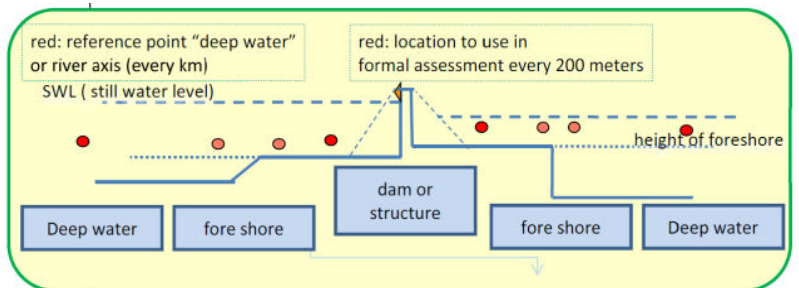

Figure 11b. Location for hydraulic load data for dams and structures (cross section)

For complex estuaries with storm surge barriers, approximately 20000 calculations with hydrodynamic models (e.g. WAQUA and SWAN) are needed. If all separate gate failure modes are included (e.g. Eastern Scheldt Storm Surge Barrier), some 7 million calculations are needed, for which a 1-dimensional hydrodynamic model is used (e.g IMPLIC [Rijkswaterstaat, 1984] or SOBEK.

Modelling the variability and statistics for wind speed and wind direction is extremely important [de Waal, 2003], [Caires et al, 2009] and [Caires 2009]; wind duration must be considered as well. Modelling the spatial variability of wind during one storm event is done rather pragmatically and not in a full probabilistic form. Research within the WTI2017 project shows that the latter is not yet feasible with the chosen approach [Jongejan, 2013]. In 2017 and 2018, research using climate models will continue the work of van den Brink [van den Brink, 2008 and 2011]. A major issue to be tackled will be calculating and processing 50000 years of SWAN wave data.
Climate models to determine the input for hydrodynamic models will be used instead of input from a mix of climate models and statistical extrapolation techniques, which were investigated up till now in the WTI2017 project [Groeneweg et al, 2012].

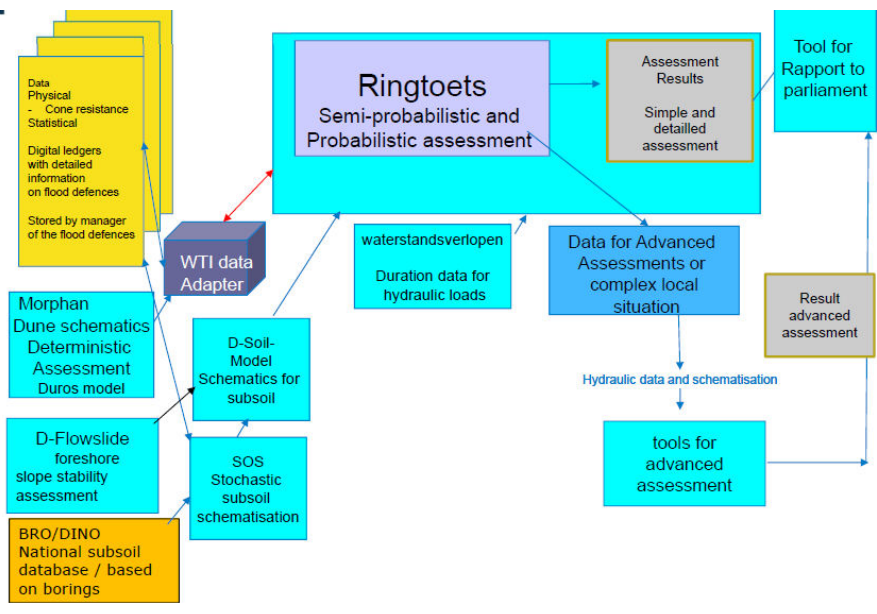

Figure 12. An overview of the WTI2017 assessment tools (software) and workflow for primary flood defences

The source code of software was written from scratch and set up in a modular way, as to allow for updating and multiple applications (assessment, design, policy and maintenance studies). The main tools (figure 12) are the user interface, "Ringtoets" and the probabilistic kernel "Hydra-Ring" (not shown in figure 12), the preprocessing tools Dsoilmodel and Morphan, and the kernels for each failure mode (also not shown in figure 12). This strategy was followed as to be sure that there are no "hidden" safety factors in the code, software errors or choices by programmers which were not documented in relevant past software.

For extremely complex flood defences, additional models and software have been developed (figure 13):

- for slope stability of the fore shore: Dflowslide

- for revetments: "Steentoets" [Breteler, 2014] [Kramer, 2015], Waveimpact [de Looff, et al, 2006], [Bokma, 2015a] and "Grastoets" [van Nieuwenhuizen, 2005], [Bokma, 2015b];

- for geotechnical analysis, like Dgflow for piping [van Esch, 2013].

\begin{tabular}{|c|}
\hline Morphan \\
Dune schematics \\
Deterministic \\
Assessment \\
Duros model \& \\
X-Beach \\
\hline
\end{tabular}
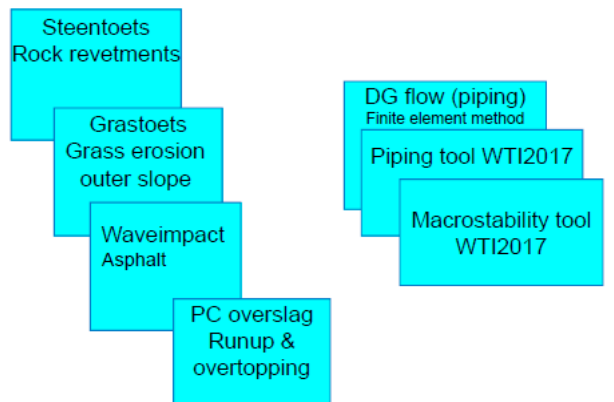

Figure 13. Advanced assessment tools (software) WTI2017 for primary flood defences

The models will first appear with a Dutch language user interface, due to the formal character of the 
assessment tools. For educational and research purposes, English user interfaces will be developed by Rijkswaterstaat in collaboration with the Delft Technical University in 2017 and 2018. However, the Hydramodels for assessment and research, Hydra-B and HydraBT for the Rhine-Meuse Estuary, are already available in English [Duits, 2004 and 2006].

\section{Data Management}

Data on flood defences has to be schematised before it can be used in the WTI2017 software. The source data and schematised data have to be accessible for other processes e.g. maintenance and for the re-design of flood defences. Having meta data is essential in this process, as it provides the link between the results of the assessment, the schematised data and the source data. This will be a major improvement compared to past assessments and compared to policy studies as VNK-2 and WV21 where this meta information was not stored.

The WTI2017 project has chosen GIS shapes files as "data carrier". The GIS coordinates of the outer boundary of the crest of the flood defence has been modelled in the National Repository of flood defence data, "Nationaal Basisbestand Waterkeringen". Per failure mode, cross sections of schematised data on flood defences are added to this file by the manager of the flood defences.

\section{Schematisation of the subsoil an iterative process}
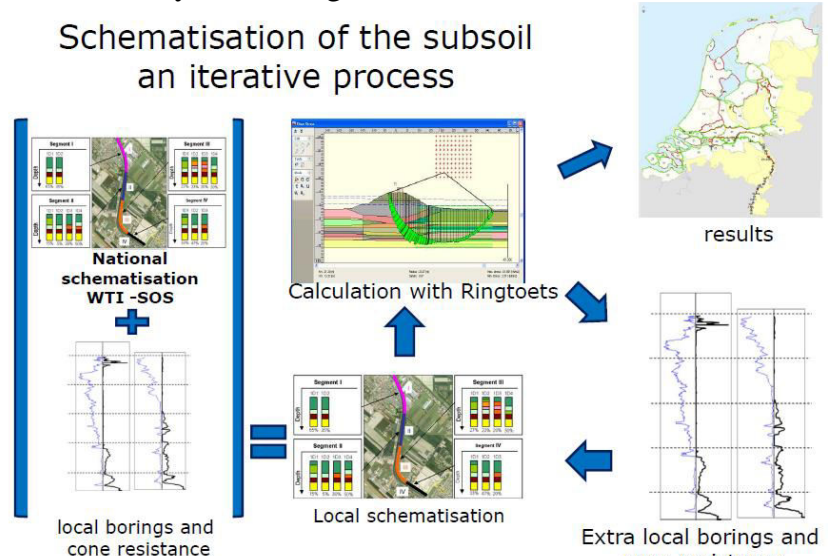

Figure 14. Schematisation of the subsoil.

A number of pre-processing tools have been developed to facilitate this process. The Dsoilmodel [van Zwan, 2016] uses the National registry ${ }^{i}$ with subsoil information based on boreholes and cone resistance data to construct a general subsoil schematisation which is geologically correct (figure 12). The user builds a local schematisation using additional information from local and dedicated measurements. This information is used in the Ringtoets model (see figure 10). If the results are not satisfactory, more field research will be necessary. Then, a new local schematisation has to be made and the Ringtoets program has to be rerun.

\footnotetext{
${ }^{\mathrm{h}}$ http://www.helpdeskwater.nl/onderwerpen/applicatiesmodel/applicaties-per/omgevings/omgevings/hydra-b/ ${ }^{\mathrm{i}} \mathrm{http}: / /$ www.broinfo.nl/
}

Introducing new software means introducing new data formats. Data management is costly and has to be done efficiently. Complicating factor in this is that the regional water authorities and most services of the national water authority, Rijkswaterstaat, have their own database systems on flood defences. Institutional barriers make common data storage choices difficult. This aspect will receive ample attention in the coming period.

Data exchange formats between software tools are being elaborated with the regional water authorities and the National Water Authority. This AQUO standard ${ }^{\mathrm{j}}$ is set by the Informatie Huis Water (IHW) in close cooperation with the WTI2017 program. Post processing tools, a national website to present all assessment results and the progress of reinforcement projects will also be developed by IHW.

Currently pre-processing tools are being (re)built to comply with the WTI2017 software standards for erosion and wave impacts on outer revetments, for wave run-up and overtopping. This will be carried out in close cooperation with staff from the regional Water Authorities. They have often built similar tools in the past.

\section{Implementation}

To facilitate the implementation of the new flood risk management policy, many extra activities within WTI2017 were carried out [Slomp, 2016]:

The national advisory committee on flood risk management, "ENW" ${ }^{\mathrm{k}}$ " has been continuously involved in quality control. In September 2016, the ENW will formally advise the minister of Infrastructure and the Environment on the technical applicability of the new tools.

The stakeholders have been closely involved:

- Engineers who manage flood defences, staff from the regional water authorities and Rijkswaterstaat, the national water authority were involved in user trials in 2014 and 2015. They were asked to give feedback on the practical applicability of the new tools and regulations. This group of stakeholders will continue giving feedback in 2016.

- Consultants who carry out a large part of the assessment. They have carried out both technical reviews and reviews on the combined use of the new regulations and software.

The new concepts from the WTI2017 project [Rijkswaterstaat, 2015] are being used in ongoing design projects. These projects still use former semiprobabilistic design practices, but with new design rules set by the WTI2017 project. Feedback from recent design projects has led to some changes in the rules and schematisation manuals.

A parallel project (OI2018) will provide a full set of new design tools in 2018 based on the WTI2017 tools. Every year, this project chooses which of available

\footnotetext{
${ }^{\mathrm{j}} \mathrm{http}: / /$ www.aquo.nl/aquo-standaard/

${ }^{\mathrm{k}}$ http://www.enwinfo.nl/
} 
WTI2017 and WTI2023 rules and tools will be made available to designers of flood defences and how to adapt assessment tools to design tools.

Policy tools will be updated from 2019 onwards. Monitoring of the policy change will start soon. Consistency between flood risk assessment tools, design tools and policy analysis tools remains essential for this policy change to succeed.

A team of experts, organised by Rijkswaterstaat and the regional water authorities in the "KPR"flood risk knowledge platform, gives advice to current individual design projects. Also consultants, who gained experience during their work for the VNK-2 project, play a large role as coaches.

An ultimate trial in September 2016, when a practice run with the new tools, documents and software with staff from all the managers of the flood defences and a large selection of the consultants will be held.

An extensive training program for staff from soil laboratories, consultants and flood defence managers has been started to introduce new rules concerning slope stability. New rules for field test and soil laboratory tests have also been elaborated.

Since 2009, the annual progress of the program was discussed with stake holders in symposia, workshops and was published on the national website "Helpdesk Water".

A general training program has been started for policy advisors (in 2015), and for engineers involved in the assessment of flood defences and design (from 2016 onwards).

A special training program was set up by Rijkswaterstaat (in 2015) to train the staff from the Human Environment and Transport Inspectorate.

As indicated in Chapter 4, a new and more professional approach to data management is needed. Two organisations are tasked to provide assistance IHW and Waterschapshuis. IHW is a collaboration between the regional water authorities and Rijkswaterstaat and provides standard definitions for all input and output variables. The IHW will provide for a postprocessing tool on the internet. Waterschapshuis is a collaboration between the regional water authorities and provides a new database structure to store data on flood defences. Waterschapshuis will provide part of the pre-processing tools. The WTI2017 project will provide financial aid to generalize data management pre-processing tools developed by regional water authorities for the others. These will be open source programmes. GIS formats (shape files) will be used to carry source data and schematized data. Proven technology with which people are familiar with, was preferred.

\section{Concluding Remarks}

The formal flood defence assessment is essential for managers of flood defences, since the national flood safety and national funding for reinforcement is based on this assessment.

The current flood defence assessment tools [VenW, 2006] are based on a mixture of probabilistic and semiprobabilistic tools. To simplify the transition for the
WTI2017 assessment tools, changes are introduced step by step. First the changes in the assessment using current methods for semi-probabilistic assessment are shown, then the managers and consultants are introduced to the full probabilistic analysis methods. The formal assessment results, being the comparison of the strength of flood defences and corresponding hydraulic loads ${ }_{2}$ is primarily based on the full probabilistic analysis.

Together with the new risk based safety standards, primarily based on flood-impact, this probabilistic flood probability assessment will allow for safety assessments and prioritisations of reinforcement measures that are implemented in a risk-based and therefore cost-effective way.

In the past, insufficient height of flood defences was often the main reason for failure in The Netherlands. Worldwide this is still the case, illustrated by recent floods in e.g. New Orleans in 2005 [Kok et al 2006], in France in 2010 [Kolen et al, 2013] and in Thailand in 2011 [Jonkman et al, 2012]. Focussing on eliminating the problems due to insufficient height of flood defences in the Netherlands for over more than 70 years, implied that some other failure mechanisms have been neglected [Jongejan et al, 2011]. The Netherlands is now prepared for disasters that occurred in the past. The policy in the Netherlands can therefor now shift to be prepared for the future. The use of the new WTI 2017 tools will make decision making for funding of flood defences more transparent and will lead to more efficient budget spending. The scarce resources for flood risk management primarily have to provide for safety and a reduction of potential damages.

Implementing new policy, rules, tools and practices at the same time can be considered a very ambitious goal. In the past, subtle changes were introduced with a frequency of once every 5 to 6 years. In 1996, probabilistic methods were formally introduced for Hydraulic loads. Semiprobabilistic methods are slowly being replaced by probabilistic approaches. Over the past 20 years the VNK project (2001-2014), its predecessors and similar policy studies e.g. WV21 (2005-2012) have prepared the Dutch flood professional community for a more risk based approach. To facilitate all these changes on January 1st 2017, a large number of accompanying programmes and projects were started in 2015 and these will continue during the transition period 2015-2019

\section{References}

Bakker W.T., Vrijling J.K. (1980), Probabilistic design of sea defences Delft University, Coastal Engineering Conference Sydney.

Bakker M, Kuijper B, Nederpel, A.C. (2010) User manual PROMOTOR, (in Dutch) version 3.

Beek V van (2015) Backward Erosion Piping. Initiation and Progression.

Bokma, J. (2015) WTI2017 Failure Mechanisms Wavelmpact Asphalt Kernel Requirements and Functional Design Version: 1.2, 2015

Bokma, J. (2015) User Interface for Grass Kernels Wave Impact and Runup Functional Design 1220079-001 
Santbergen, P (2005), User Manual Hydra-Tools, (in Dutch) version 1.3

Brekelmans, R, Eijgenraam, C, Hertog den D., Roos K, (2014) A Mixed Integer Nonlinear Optimization Approach to Optimize Dike Heights in the Netherlands, Optima 94, Mathematical Optimization Society Newsletter.

Breteler, M. K., (2014)User documentation revetment assessment program "Steentoets" (in Dutch) Documentatie Steentoets, Excel-programma voor het berekenen van de stabiliteit van steenzettingen,

Brink, H. W. van den, and Können G. P. (2008), The statistical distribution of meteorological outliers, Geophys. Res. Lett., 35, L23702, 2008

Brink, H. W. van den. and Können G. P, (2011) Estimating 10000-year return values from short time series. Int. J. Climatol., 31: 115-126. 2011

Brink, H.W. van den, (2015) Extrapolatie van de waterstand in het Waddengebied, Henk van den Brink KNMI (in Dutch)

Chbab, H, Noortwijk, J.M., Kalk, H.J. (2002)Baysian Estimation of Extreme river Discharges, Bern, IHR/CHR

Chbab, H. ) (2016) Basisstochasten WTI-2017 Statistiek en statistische onzekerheid (in Dutch

Caires, S, J.P. de Waal, G. Groen, N. Wever and C.P.M. Geerse, (2009): Assessing the uncertainties of using land-based wind observations for determining extreme open-water winds SBW-Belastingen: Phase 1b of subproject "Wind modelling", Deltares, KNMI and HKV, The Netherlands

Caires, S (2009)] Extreme wind statistics for the Hydraulic Boundary Conditions for the Dutch primary water defences SBW-Belastingen: Phase 2 of subproject "Wind Modelling" 2009

CUR, Civieltechnisch Centrum Uitvoering Research en Regelgeving, (1990) Probabilistic design of flood defences, Center for applied research in construction, , Rotterdam, The Netherlands, 1990

van Dantzig, D. (1956) Economic decision problems for flood prevention, Econometrica 24: 276-287, 1956

Deltares, (2016) SOBEK Hydrodynamics, Rainfall Runoff and Real Time Control, User Manual, 2016,

Deltawet, 1958 (in Dutch) http://wetten.overheid.nl/BWBR0002283/geldigheidsdatu m_27-09-2005

Diermanse F, (2016) Overzicht van belasting- en sterkteonzekerheden in het wettelijk toetsinstrumentarium

Duinmeijer, S.P.A. (2002) Verification of Delft FLS,

Duits, M.T. (2004), User manual Hydra-B, version 3.1. advanced users (in English)

Duits, M. T. (2006), User manual Hydra-BT, Version 1.2 (in English)

Esch, van J.M. (2013) Modelling transient Groundwater Flow for Stability Assessment of Dikes 1206015-003 (C) Deltares, 2013

Geerse, C.P.M. (2011) Hydra-Zoet for the fresh water systems in the Netherlands Probabilistic model for the assessment of dike heights, HKV, Lelystad, The Netherlands, 2011

Graaff van de J. (1986) Probabilistic design of dunes; an example from The Netherlands Coastal Engineering de Grave, P, (2014) User manual, in Dutch, KosWat, "KOSten voor versterken WATerkeringen" (in Dutch),

[Groeneweg J. Caires, S. and Roscoe K, (2012) Temporal and spatial evolution of extreme events, coastal Engineering, 2012

Ham van der, W. (2004) Afleiden of opruimen, De strijd om de beste aanpak tegen het rivierbederf een beschou-wing van 300 jaar rivierverbetering in het kader van de spankrachtstudie, Rijkswaterstaat (in Dutch), "Examining three hundred years of river diversion projects"

Heijer den F., Vos, R.J. and Gautier, C. (2008), Probabilistic approach for safety assessment of water defences along the Dutch coast, model and verification, ICCE 2008

Hegnauer M., Beersma, J.J, Boogaard, H.F.P. van den Buishand, T.A., Passchier, R.H., Lammersen R. and Buiteveld, H. (2016) Generator of Rainfall and Discharge Extremes (GRADE) for the Rhine and Meuse basins Final report of GRADE 2.0

[IenM, 2016] Waterwet, proposed changes to the Water Act, Ministry of Infrastructure and the Environment,https://wetgevingskalender.overheid.nl/Reg eling/WGK005903 (in Dutch)

Jongejan, R.B., H. Stefess, N. Roode, W. ter Horst \& B. Maaskant, (2011) The VNK2-project: a large scale quantitative flood risk analysis for The Netherlands. 5th International Conference on Flood Management (ICFM5), 27-29 September 2011, Tokyo-Japan

Jongejan, R.B. (2013) Probabilistic assessments of block revetments in the WTI2017 Alternatives and proposed course of action

Jongejan R.B. and Calle, E.O.F. (2013) Calibrating semi-probabilistic safety assessments rules for flood defences, Georisk: Assessment and Management of Risk for Engineered Systems and Geohazards, April 2013

Jonkman, S.N., Vardhanabhuti Barames, Blommaart, P., Bruin, B. de, Hardeman B., Kaensap, K, . Meer, M. van der, Schweckendiek T., Vrijling J.K, (2012) Postflood field investigation in the Lower Chao Phraya River Basin Findings of the Thai-Dutch Reconnaissance Team

Kind, J. (2010) Cost-benefit analysis for flood protection standards in the Netherlands, Deltares, Delft

Kok M., H.J.. Vrouwenvelder A.C.W.M., Barendregt, (2005) A. Standard Method 2004, Damage and Casualties Caused by Flooding, DWW (Rijkswaterstaat), 2005

Kok, M, Theunissen R., Jonkman S.N., Vrijling J.K. (2006) Schade door overstroming: Ervaringen uit New Orleans (in Dutch),

Kolen, B, Slomp, R, Jonkman (2013) The impacts of storm Xynthia February 27-28, 2010 in France: lessons for flood risk management Journal of Flood Risk Management 6 (3), 261-278, 2013

Kramer, J. (2015) WTI/RTO Package: Block Revetment Failure Mechanism Library Steentoets Functional Design Version: 21 September 2015

Lodder Q.J. and Geer, van P.F.C. (2002) MorphAn: A new software tool to assess sandy coasts

Looff, de A.K., 't Hart R., Montauban K.,. Ven van de, M.F.C. (2006) Golfklap, A model to determine the impact of waves on dike structures with an asphaltic concrete layer, Rijkswaterstaat 
Meer, van der J.W. (2002), Technical report wave run-up and wave overtopping at dikes, TAW

Meermans, W. (1999) Onzekerheidsanalyse HydraM: onzekerheid en de invloed daarvan op het met reprofuncties berekende kruinhoogtetekort voor dijken rond het IJsselmeer

Moll, R and Meulepas G.J. (2008) Syntheserapport Compartimenteringsstudie, Rijkswaterstaat

Most van der H., Tánczos I., Bruijn, K.M. de Wagenaar,, D. (2014) New, risk-basis standards for flood protection in the Netherlands, ISFM6, Sao Paulo, Brasil, September 2014.

MNP, Milieu- en Natuurplanbureau, (2004) ten Brinke, W.B.M. and Bannink, B.A., Risico's in Bedijkte Termen, een evaluatie van het beleid inzake de veiligheid tegen overstromingen, (in Dutch) May 2004,

Nieuwenhuizen, L van. (2005), Gebruikershandleiding GRASTOETS v.3 Spreadsheetprogramma voor toetsing van grasbekledingen volgens VTV, Rijkswaterstaat Directie Zeeland, Projectbureau Zeeweringen, P2404.B0

Nillesen A.L. and Kok M (2015) An integrated approach to flood risk management and spatial quality for a Netherlands' river polder area.

Peters T, Berg, van den F. (2016) Rapid Assessment Tools for Dam Safety, Second National Dam Safety Conference, 12-13 January 2016, Bengaluru

Rijkswaterstaat (1984) "Eastern Scheldt Barrier design document on Hydraulics for a prefabricated design", Onderzoek naar de mogelijkheid van afsluiting van de Oosterschelde met een gedeeltelijk geprefabriceerde stormvloedkering, report \#2, (in Dutch)

Rijkswaterstaat, (2012) WAQUA/TRIWAQ -two- and three-dimensional shallow water flow model.Technical documentation SIMONA

Rijkswaterstaat, (2015), Achtergrondrapport Ontwerpinstrumentarium 2014, Behorende bij Handreiking Ontwerpen met Overstromingskansen

Roelvink, J. A., Reniers, A. J. H. M., van Dongeren, A. R., van Thiel de Vries, J. S. M., McCall, R. T., and Lescinski, J. (2009). Modelling storm impacts on beaches, dunes and barrier islands. Coastal Engineering, 56(11-12):1133-1152.

Roscoe, K. Diermanse, F.,. Lopez de la Cruz J,. Steenbergen, H Vrouwenvelder T.2012) Hydra Ring Scientific Documentation, 1206006-004, Deltares / TNO

Sellmeijer, J.W. (1988) On the mechanism of piping under impervious structures

Slomp, R.M. (2012) Flood Risk and Water Management in the Netherlands, A 2012 update, Rijkswaterstaat,

Slomp, R.M., J.P. de Waal, E.F.W. Ruijgh, T. Kroon and J.S.L.J. van Alphen, (2014). The Dutch Delta Model for Policy Analysis on Flood Risk Management In the Netherlands. 6th International Conference on Flood Management (ICFM6), September 2014, Sao Paulo, Brazil

Slomp, R.M. (2016), Implementing risk based flood defence standards, Rijkswaterstaat.

Stijnen J.W., Maaskant B., Silva W. and Slootjes N., (2008) Towards a different safety standard in the Netherlands? Uncertainty analysis in a flood-risk approach Geophysical Research Abstracts, Vol. 10, EGU2008-A-00000

Technical Advisory Committee on water Defences, (1998) Fundamentals on Water Defences, Guidelines for Water Defences, 1998

Vanmarke, E. (2011) Risk of Limit-Equilibrium Failure of Long Earth Slopes: How it Depends on Length, Georisk International Conference, Atlanta 2011

VenW, Ministry of Transport and Water Management (1996) "Wet op de Waterkering", Flood Defence act http://wetten.overheid.nl/BWBR0007801/geldigheidsdatu m_04-12-2009 (in Dutch)

VenW, (2001) "De veiligheid van de primaire waterkeringen in Nederland, Achtergrondrapport". Formal report on the state of the flood defences in 2001, a policy study (in Dutch) Ministry of Transport and Water Management, 2001

VenW, (2006) Voorschrift Toetsen op Veiligheid 2006 and Hydraulische Randvoorwaardenboek 2006, Ministry of Transport and Water Management, (in Dutch)

VenW, (2009) "Waterverordening", Regulations for Water management, Ministry of Transport and Water Management (in Dutch), http://decentrale.regelgeving.overheid.nl/cvdr/XHTMLoutput/Historie/ Zuid-Holland/72380/72380 1.html

Vrijling, J.K. Bruinsma, J. (1980) Hydraulic Boundary Conditions. In: Proceedings on Hydraulic Aspects of Coastal Structures; developments in hydraulic engineering related to the design of the Oosterschelde storm surge barrier in the Netherlands. Editors: A. Paape, J. Stuip, W.A. Venis, Delft University Press 1980, pp. 109 - 133, ISBN 90-6275-0540.

Vrouwenvelder, A.C.W.M., Steenbergen, H.M.G.M., Slijkhuis, K.A.H., (2001) Theoretical manual of PC-Ring, Part A: descriptions of failure modes (in Dutch), Nr. 98CONR1430,Delft

Vrouwenvelder, A.C.W.M., Steenbergen, H.M.G.M., Slijkhuis, K.A.H., (2001) Theoretical manual of PC-Ring, Part B: Statistical models (in Dutch), Nr. 98-CONR1431, Delft 2001.

Vrouwenvelder, A.C.W.M., (2001) Theoretical manual of PC-Ring, Part C: Calculation methods (in Dutch), 98-CON-R1204, Delft 1999.

Vrouwenvelder A.C.W.M., Steenbergen, H.M.G.M. Diermanse F.L.M. (2002) Belastingmodellen Benedenrivierengebied - fase $2 /$ Concept met aanvullende berekeningen. Vrouwenvelder, -rapport 2001-CONDYN-R8014. TNO-Bouw, (in Dutch)

Vrouwenvelder, T. (2006). "Spatial Effects in Reliability Analysis of Flood Protection Systems.' Proc. 2nd Int. Forum on Engineering Decision Making, Lake Louise, Canada, April 2629, 2006.

Vrouwenvelder, A.C.W.M., (2008). "Treatment of Risk and Reliability in the Eurocodes." Proceedings of the Institution of Civil Engineers Structures and Buildings 161 (SB4):209_214.

Waal, JP de, (2003), "Windmodellering voor bepaling waterstanden en golven", (in Dutch) Wind model used for flood defence assessment, RIZA \#2003.118x

Waal, JP de, Editor, (2014) Uitgangspunten WTI 2017, (in Dutch) "Terms of reference" 
Waal, JP de, Editor, (2016) Basisrapport WTI2017, General Introduction to the WTI2017 (in Dutch)

Zijlema, M., , (2007) TU Delft, SWAN, User Manual, SWAN Cycle III version 40.51, 2007.

Zwan, van I. van and Vastenburg E. (2013) User Manual, Handleiding DAM 1.0 (in Dutch)

Zwan, van I. (2016) User Manual Dsoilmodel (in Dutch), 